\title{
Acquisition of Land for Housing Societies in Pakistan: Gap between Theory and Practice
}

\author{
MIRZA SHAHID RIZWAN BAIG \\ Assistant Professor of Law \\ College of Law, Government College University Faisalabad. \\ Email: shahidrizwan39@gmail.com \\ HAFIZ MUHAMMAD USMAN NAWAZ \\ Assistant Professor of Law \\ International Islamic University, Islamabad, Pakistan. \\ Email: usman.nawaz@iiu.edu.pk \\ Dr. RAO QASIM IDREES \\ Assistant Professor of Law \\ School of Law, University of Gujrat, Punjab, Pakistan. \\ Email: qasim.rao@uog.edu.pk
}

\begin{abstract}
In order to start a housing society acquisition of land is a first step and the Land Acquisition Act 1894 also encourages the housing companies as it is reflected from the preamble of this Act. This enactment is the most important law relating to housing industry of Pakistan. When this enactment was promulgated its preamble was designed in such a way that private sector along with Government is encouraged to acquire land for public purposes. This enactment is a double-edged instrument. For Pakistan this enactment in its present shape is not proving to promote housing industry rather a major reason for undermining investment in the housing industry of Pakistan. Most of the housing societies in Pakistan do not acquire land for the housing societies under Land Acquisition Act 1894, so, there is a gap between theory and practice. The actual practice is that housing developers purchased lands from their own resources at high prices and then sell it on very high prices resultantly providing housing units to only rich people. In its present shape there is a very cumbersome process to acquire land under Land Acquisition Act 1894 and the Act hinders the speedy acquisition of land for housing industry. Land Acquisition Act 1894 provides for payment of compensation of land acquired on the basis of market value but in practice the price of the lands acquired under this Act are paid on the basis of registration documents which are undervalued. There is massive litigation on the point of determination of market value additionally, approves the position to get land apparently for a 'public reason', inside the importance of the Land Acquisition Act, 1894. The article aims to explore and analyze the relevant law with respect to acquisition of land for housing societies as well as to find out obstacles faced by housing societies in acquiring the land. The discussion would also be helpful to check the efficacy of present law of land acquisition in achieving goal of housing for all. For that critical analysis of the relevant laws is done by using qualitative sort of research.
\end{abstract}

Keywords: Land Acquisition Act 1894, Housing Societies, Pakistan, Gap, Theory and Practice. 


\section{Introduction}

\section{The Concept of Public Purpose Vis-A-Vis Housing Industry of Pakistan}

Among other factors the decisive factor to decide, whether housing should be a poverty alleviation measure or merely a pure business activity, is the pattern and legal framework to acquire land for the housing activity in Pakistan. The first step to start a housing society is purchasing or acquisition of land for the housing society. It is essential requirement in whatever form (cooperative housing society, private housing society etc.) housing activity is performed. During the age of British rule, in order to encourage the private sector (companies), the acquisition of land for companies was acknowledged in the preamble of the Act but due to ambiguity in the enactment there is divergence of opinions, there are different interpretations of different courts (Rizwan, 2017).

In Haq Nawaz Khan and others $v$ Rab Nawaz and others, the owner of the land remains owner of the land even after issuance of notification under section 4 of the Land Acquisition Act 1894.The land shall vest in the Government after the taking over the possession of the land by the collector. Land would vest in the Government when the possession of the land has been taken over by the collector. Land in question was acquired by Lahore Development Authority for establishing a housing scheme. Plaintiffs purchased land from the owners of the lands after the notification for the acquisition of land had been issued by the authorities (1992 SCMR 993).

Plaintiff challenged the notification of acquisition. It was a matter between original owners and the plaintiffs. The acquisition of land by Lahore Development Authority could not be challenged by the plaintiffs as they did not exist on that time. The original owners were entitled to compensation only (2011 YLR 3060).

Government has been given authority to judge whether land is needed for a public purpose or not. So, the decisive authority lies with the Government concerned to decide whether declaration should be issued under section six of the Act or not. The Government is the sole judge to decide whether there is a need and whether the need is for public purpose or not. If there is a colorable exercise of powers, the declaration of the Government can be challenged at the instance of aggrieved party (land owners), due to this reason there is a lot of litigation which is faced by the developers of the housing industry. No check can be imposed on the powers of the apex court of Pakistan to check whether the land is being acquired for a public purpose or not (AIR 1962 SC 764).

\section{Encouragement of the Private Housing Companies by the Land Acquisition Act 1894.}

For carrying out the housing activity the law encourages to acquire land and this fact is reflected in the preamble of the Land Acquisition Act-1894 which reads as under "Where it is expedient to amend the law for the acquisition of land needed for public purposes and for companies and for determining the amount of compensation to be made on account of such acquisition" (Gates, 1968).

The intention of the legislature can be inferred from the preamble of the Act, which is to promote the private sector to invest in the housing industry of the country. This enactment encourages the acquisition of land for public purpose. Public purpose can be equated with any welfare contributing objective such as construction of schools, hospitals, roads and dams.

The initiative for the welfare of the public can be taken by the public as well as by the private sector. The inclusion of the word for the companies connotes the intention of the legislature to encourage the private sector to acquire the land under the provisions of Land Acquisition Act 1894.The use of the words public purpose and a company does not exclude and is not inconsistent with the view that the purpose even in the case of acquisition for a company should be a public purpose (AIR 1955 Andhra 184). 
There is no contradiction in the words public purpose and company and these words are used to acquire land for companies' i.e. private sector (AIR 1954 Madras 481). When the private housing scheme applied for no objection certificate (NOC) to the development authority to launch housing scheme, after filing this application by the private housing scheme, the development authority issued a notification under section 4 of Land Acquisition Act 1894 to acquire the land for the housing society of the authority owned by the development authority.

The private housing scheme challenged the notification that there was a conflict of interest of the private housing scheme and the development authority. As development authority wanted to establish a housing scheme on the land of the private housing company and due to this clash of interest the development authority did not accept the application of the private housing company.

High court set aside the order of issuance of notification being malafide, discriminatory and in violation of fundamental rights. It was also declared to be against the intention of the legislatures of the Land Acquisition Act 1894 as well, which intended to promote companies to do public welfare activities (2016 CLC 408).

\section{The Definition of Public Purpose in Relation to Acquisition of Land for Housing Activity.}

It is essential that the word public purpose should reflect from the preamble of the enactment and if it is not mentioned in the preamble then it cannot be added subsequently by way of affidavit by the legislatures of the enactment. The word public purpose is clearly reflecting from the preamble of Land Acquisition Act in explicit words (Nadeem, 2020).

Public purpose in the context of the Act includes the provision of village sites in districts. The definition of public purpose is not definite about the activities which may be declared as public purposes. Due to vagueness of the definition of public purpose in the Act every acquisition of land is challenged to decide whether land acquired in the given cases is acquired for public purpose or not, so a flood gate of litigation is opened. The word public purpose has been interpreted by various courts in a different manner.

Land acquisition is founded upon the doctrine of salus populi suprema lex (1990 MLD 2158). It means the collective interest of the public should be given preference over the individual interest of the person. But this provision does not provide unbridled powers to the Government to take over the property of any citizen in the country (Das, and Mathur, 2006).

\section{Whether Acquisition of Land for Housing Activity is Against Constitutional Guarantee?}

Constitutional guarantee has been provided under the Constitution of Islamic Republic of Pakistan 1973.As per Constitution of Islamic Republic of Pakistan 1973, no property shall be compulsory acquired for a public purpose, save in accordance with law and after payment of compensation (Constitution of Islamic Republic of Pakistan, 2016). Apparently there seems to be a contradiction in the above mentioned provisions but in fact it is not the case. Article 24 of the Constitution of Islamic Republic of Pakistan 1973 is explanatory to the provisions of the Act that land can be acquired for a public purpose but it can be done after following the due process of law and after payment of compensation to the land owners if the land is being acquired for a public purpose.

Private lands are acquired under the provisions of Land Acquisition Act 1894 for public purpose without consent of the owners of the land and paramount consideration behind this acquisition of land is the welfare of the general public. Object behind the legislative dispensation is not to deprive the land owners of their Constitutional rights. Such rights are secured under Articles 23 and 24 of the Constitution of Islamic Republic of Pakistan 1973.Property can be acquired under the Act but after payment of compensation (PLD 2002 SC 91). 
No individual property can be acquired except in accordance with law and subject to payment of compensation (PLD2002 SC 706). No private property could be acquired except for public purpose and in accordance with law and after making compensation for it (PLD 1983 SC 457).

Land Acquisition Act 1894 was enacted many years before the Constitution came into force and the provisions therefore would accordingly appear not to be subject to the Constitutional limitations on the acquisition of property .It is a law which was made by a competent legislature before the Constitution and it did not become invalid immediately on the Constitution coming into force (AIR 1958 Allahabad 872).

Right to fair trial has been recognized as a fundamental right under Article 10-A of the Constitution as a fundamental right. Depriving any person to raise an objection against the deprivation of his right to property would be denial of the right to fair trial (PLD 2016 Lahore 293).

So, the after combine reading of the above mentioned provisions of law the position is that property cannot be taken from anybody save in accordance with law and after payment of compensation. The person whose land is being acquired has a right to file to challenge the purpose for which land is being acquired as well as the amount of compensation can be challenged.

\section{Open Ended Definition of Public Purpose and Interpretation of Courts}

The word public purpose has not been defined in the Land Acquisition Act 1894 in explicit and definite words, so, there is a lot of room for the interpretations by the courts. Most of the cases are those where the acquisition of land has been challenged to decide whether the purpose for which land is being acquired is a public purpose or not.

The collective interest would be preferred over individual interest of the person. The expression public purpose has wide scope under the Act and any act which is beneficial for the larger segment of the society should be included in the definition of public purpose (PLD 1964 SC 60).

Public interest has been further elaborated, as per the judgment any purpose furthering general interest of community as opposed to particular interest of individuals is included in public purpose. Now a question arises whether each and every member of the society should be beneficiary of the society and then it would be called a public purpose or if some members of the society are taking benefit of the land acquisition for fulfilling the requirement of public purpose. Where there is a shortage of housing units, the acquisition of land to remove this shortage of housing units is a public purpose (Ali, 2019).

It is perfectly a legitimate policy on the part of the Government, when there is an extraordinary shortage of housing units in Delhi. It amounts to public purpose if the land is being acquired by the Government for the establishment of cooperative housing societies. The purpose of the definition is served when only a section of the society is taking benefit in the shape of housing units; still the meaning of public purpose is served (AIR 1959 PB 479).

But here a problem arises if the land is being acquired by the rich people for the rich people only by excluding the poor segments of the society, can we call it land acquired for public purpose if it is to serve the interests of elite class only. The word public purpose indicates a purpose in which the general benefit of the society as compared to the special interest of a class of people is served (AIR 1925 Mad 837).

Another view point is that the word public purpose cannot be defined strictly and due to this reason the definition of public purpose has been left open ended with a purpose to meet the requirements of the time to interpret it in future times according to the needs of the society. So, in spite of the fact that there is a lot of litigation on this point i.e. whether the land is needed for public purpose or not and what is meant by public purpose. 
With respect to public purpose as defined in Section 3(f), it has been laid down by the Supreme Court in many cases that the purpose of the Act would not be served by giving it a rigid meaning so it is an elastic concept which has a meaning according to changed circumstances. It is now universally agreed that any concept of public purpose bound in the strait jacket of any rigid formula is inconceivable (AIR 1978 Patna 136).

The word public purpose has different connotation in different times.Due to this reason no closed ended definition has been provided by the legislature and it has been left to the Government concerned to determine whether a public purpose would be served ina given case or not. To acquire land for a special class of people is not a violation of Fundamental rights and it will remain a public purpose for determining the acquisition of land under the Act and Punjab Private Site Regulations 2005 (AIR 1963 SC 151).

The expression public purpose has no precise and rigid meaning except that it should have benefit for the public in general instead of an individual benefit (PLD 1983 SC 457

\section{Two Views about the Definition of Public Purpose.}

There are two opinions on this point of view, one is that there is no need to strengthen it and there is no need to modify and improve the definition of public purpose and it can serve the needs of the housing industry. Second view point is that there is a need to modify, improve and strengthen the definition of public purpose in the Land Acquisition Act 1894, to save the housing developers from prolonged and lengthy litigation.

\section{Acquisition of Land Not for Public Purpose.}

Acquisition of land for construction of housing units for members of a particular cooperative housing society cannot be said to be an acquisition for public purpose. The general interest of the public is the precondition for acquisition of land for public purpose. Where the purpose of the acquisition of land is to acquire the land even for construction of housing units it cannot be called acquisition for public purpose if the object is to serve the interest of a few individuals (AIR 1971 Gujarat 158).

When the statute does not define public purpose at all no presumption arises as to the existence of a public purpose (AIR 1952 SC 252). After acquisition of land for public purpose the utilization of same land for any other purpose is not a public purpose (ILR 18CAT.99 (PC). Where the acquisition is proved to be not for public purpose but with an ulterior object, extraneous to the scope of the Act, the notification by the Government can be set aside (ILR 48 CAL.916).

The land of the petitioner was being acquired for LDA Avenue-1 Housing Scheme under Land Acquisition Act 1894 under the definition of public purpose. Petitioner being Pakistani was settled abroad and had purchased land with hard earned income. The grievance of the petitioner was that his land could not be acquired due to protection available to him under Protection of Economic Reforms Act 1992. High court found petitioner entitled to exclusion of his property from the operation of scheme. Petition was accepted and the acquiring authority was stopped to acquire the land under Land Acquisition Act 1894 (CLD 850).

The land acquisition for the personal benefit of a particular class of employees would not be in the public interest, so it cannot be called land acquisition for public purpose (2000 YLR1711). Land was not the need of the society but it was acquired for the purpose of establishment of a residential colony and the same was for the benefit of few individuals. Acquisition of land for such a purpose was like committing a dacoity on the valuable rights of the citizens (2000 MLD 322).

The purpose of construction of dwelling houses cannot be considered necessarily or per se to be a public purpose. Construction of houses in an area where the dwelling accommodation is in excess of requirement cannot advance a public purpose. Similarly, construction of houses in a heavily congested area or in slums 
area cannot be said to serve a public purpose because it would only worsen the congestion and thereby adversely affect the health of the public (AIR 1959 Punjab 544).

Where the land was already acquired for the members of the cooperative housing society the land could not be acquired for Lahore Development Authority under the provisions of Land Acquisition Act for public purpose. Members of the cooperative housing society were already poor people so the notifications issued for the acquisition of land for the LDA society were set aside as the members of the cooperative housing society were poor people they were more deserving. LDA society could not get the land for public purpose (PLD2016 Lahore 293). When acquisition of land is only to enrich a special group of people any such acquisition would be unjust enrichment and it would be negating public purpose (1996 SCMR 1277).

\section{Overnight Change of the Nature of Land from Agriculture to Commercial by Revenue Department to Enable Owners to Claim More Compensation from Housing Developers.}

Societies tend to get heavily bogged down during the process of land acquisition. As soon as a housing society is launched in a particular area, cost of adjoining land immediately appreciates. The revenue department, the representatives of the local Government of the area concerned in which housing society is being launched and opportunist land dealers all jump into the arena to exploit the situation to their advantage.

They all assume the shape of a mafia and dictate their terms to the housing developers concerned. There are no legal means available to the developers of the housing societies to purchase the land for the housing societies without bribing the officials of the revenue department and other people i.e. owners of the lands.

If Government of Pakistan is serious to achieve the goal of housing for all then it needs to strengthen its legal framework to save the exploitation of the developers of the housing societies at the hands of the land mafias. At the time of getting approval for the housing scheme from the relevant development authorities the developer is required to submit the lay out plan of the hundred percent lands including that portion of land which is yet to be acquired.

After getting the approval from the development authority, when the developers proceed to purchase the portion of land initially not purchased, but included in the master plan, they face a hardship. They face hardship when the pages in the revenue record are replaced by the revenue authorities with the pages which show the nature of the land as commercial one.

This fraud is done by the owners of the adjoining lands in connivance with revenue officials to charge commercial rates of their lands which are included in the master plan. Due to this blackmailing the developers are forced to pay high prices of the lands included in the master plan but which are purchased after getting approval from the relevant development authorities.

In this state of affairs the record of revenue department cannot be considerd as a conclusive proof the nature of the land (1999 SCMR 125). As per law the developers of the housing societies are required to file lay out plan of the whole site on which housing society is to be established by including both areas of lands i.e purchased portion and the portion of land yet to be purchased with the authority or Tehsil Municipal Administration (TMA).After grant of approval of the housing society when efforts are made to purchase that part of land which is included in the layout plan of the housing society but which has not been purchased yet the owners of this piece of land expoloit the situation by demanding exceptionally high prices.

Owners of thois portion of land take the cover of Constitutional protection that nobody can be deprived of his property without proper compensation and without following the due process of law but the developers 
of the housing societies fell themselves as helpless due to non-availability of a legal remedies (Constitution of Islamic Republic of Pakistan 1973).

So, the developers of the housing industry become victims at the hand of land owners and land mafias. Government of Pakistan in order to protect and encourage the housing industry should take steps to strengthen the Legal Framework relating to housing industry in general and Land Acquisition in particular.

\section{No Remedy Available to Aggrieved Developers under the Legal Framework of Pakistan if Higher Market Rate is charged by Land Owners.}

As per latter and spirit of the Land Acquisitions Act 1894, if land is acquired by the private housing companies or cooperative housing societies and if an amount less than the market value is fixed by the collector the land owners have got a remedy under section 18 of the Act but if contrary to it if an amount more than the market value is fixed by the collector then the private housing company or the cooperative housing society has got no legal remedy.

Any person who is aggrieved from the order of the collector regarding the area of land being acquired, the measurement of the land, the amount of compensation, any reservation about the distribution of the amount of compensation, may file a written application to the collector of the area concerned. There is a remedy available to the owners of the land if fewer amounts are paid as a compensation for acquiring land.

The owners of the land by exercising their constitutional right and the right provided by the Land Acquisition Act 1894 can file reference to the court for getting high amount of market value of their lands (PLD 1995 SC 418). In this way the housing societies are delayed, when even after payment of appropriate amount of compensation, the land owners commit abuse of the process of law by filing frivolous litigation to claim more compensation. Housing developers are blackmailed to pay prices of the lands according to the wishes of the land owners.

Very interesting to note that the aggrieved housing developers i.e. housing company or the cooperative society has no remedy even if these are aggrieved one and it was decided by the supreme court of Pakistan in the case of Pakistan Vs. Abdul Hayee Khan (The Land Acquisition Act-1894).

It has been reaffirmed in these words that we are not inclined to agree with the contention of learned Deputy Attorney general for the reason that full bench of this court after taking into consideration all attending circumstances of the case and the law on the subject. The court is of the opinion that a reference under section 18 of the Land Acquisition Act 1894 before the referee court by a beneficiary is not competent (2006 SCMR 402).

Whether a housing company could file appeal against the judgment passed by the referee court. High Court answered the question in negative. High Court gave its decision on the basis of the decision of Supreme Court of Pakistan in Peer Khan case (PLD 1987 SC 485). Order of the civil court on reference made to it by the land acquisition collector was final and application could only be filed by the land owners only if they feel themselves as an aggrieved (1989 SCMR 812).

In another case when this matter came under consideration of the highest court of Pakistan once again it declared in very clear words that beneficiary of the acquired land has no right and locus standi to either file reference against the award of compensation or appeal. Beneficiary housing company cannot file appeal against the judgment arising out of reference under section 18 of Land Acquisition Act 1894. Petition for leave to appeal by the beneficiary being not maintainable was dismissed by the Supreme Court of Pakistan (2009 SCMR 1051). Shariat appellate bench of Supreme Court of Pakistan in its judgment has declared section 18 of Land Acquisition Act 1894 being in contravention of injunctions of Islam as it prohibited appeal or reference to be filed by the housing company or the developers of the housing industry (1997CLC 
556). Furthermore, Land Acquisition Act 1894 is based on the rule to rob Peter to pay Paul. There is no scope for such type of action in an Islamic state, as it offends the injunctions of Islam and this rule has no place in an ideological state like Pakistan (2000 MLD 322).

\section{Remedy available to the Aggrieved Housing Companies (Developers) in India.}

A contrary view taken by the apex court of India is very important in Indo Swiss Time vs. Umro case, in which the interpretation of the word person interested in the Act is an inclusive one and not closed ended. After acquisition of land by the acquiring agency of the Government the land is transferred in the name of the company. Company is included in the meaning of word person used in the Act because it is interested in the matter that a proper amount of compensation is paid to the land owners. So, the apex court of India has provided a relief to the developers of the housing industry by filing a reference under Section 18 of the Act if they are forced to pay undue amounts to the land owners.

\section{Need to Provide Right Of Representation to Developers Of the Housing Industry.}

As per section 18 of the Land Acquisition Act 1894, any person who has not accepted the award may file a written application to the collector if he has any objection regarding measurement of the land, the amount of compensation, the person to whom it is to be payable or the apportionment of the compensation.

A careful examination of this provision indicates that, it is a clear injustice which is being done to the housing developers in Pakistan that a housing company or a cooperative housing society for whose benefit the land is being acquired under the law and which is supposed to pay the market value of the land if aggrieved by the amount of the market value is not a person interested and it has got no remedy.

Company was thus held to be person interested within the meaning of section 18 of the Act in the jurisdiction of India (1981 H 213 (FB)). It is need of the hour that in order to promote the investment in the housing industry of Pakistan by the private sector the housing developers should also be treated as a person interested under section 18 of Land Acquisition Act 1894.

Universal declaration of Human rights declared housing as a right and it has been subsequently reaffirmation at the 1996 UN Habitat conference as "Adequate Shelter for All" ().According to the planning commission of Pakistan shelter is one of the basic necessities of life and occupies the biggest portion of any human settlement but there is a huge shortage of housing units in the country.

Meeting the backlog in housing industry of Pakistan is beyond the financial resources of the Government of Pakistan. This necessitates putting in place a legal framework to facilitate financing in the housing industry by the private sector and mobilize non-Governmental resources (News Paper Daily Dawn, 4 September 2017).

An investment of rupees nine hundred and fifty billion is envisaged in the Medium Term Development Framework (MTDF) for the development of housing. Out of this amount about nine hundred and twenty billion investments by the private sector and rupees thirty billion investment by the public sector is expected (Medium Term Development Framework 2005). Government alone cannot meet the housing shortfall so Government will Act as a facilitator instead of a developer (National Housing Policy 2001). If the whole amount of public sector development programme (PSDP) is spent on housing activity and leaving no money for any other development work even then Government of Pakistan cannot achieve the goal of housing for all as envisaged under the UN Habitat agenda without the help of the private sector.

Under the above scenario when the housing companies and cooperative housing societies will be forced to acquire remaining 10\%(it was 20 percent under rules of 2005) land on very high prices under section 9 subsection $(\mathrm{h})$ of the rules of 2010. The situation is further worsening when the housing developers have no 
recourse to the court (as housing developers are not included in the definition of person interested). Due to the above said issues faced by the developers of the housing industry of Pakistan the developers of the housing industry do not follow the procedure prescribe by the Act for the acquisition of land and these housing developers resort to purchase the lands directly from the owners of the lands from their own resources and without following the procedure prescribe by Land Acquisition Act 1894. When the developers purchase lands from their own resources on very high rates then afterwards only rich people can afford to purchase a plot in the housing societies developed by these developers.

From this very stage of the development of the housing societies middle class and poor class of Pakistan are out of race to have their own housing units. So, there is a gap between theory and practice in the legal framework of Pakistan relating to housing industry of Pakistan. In order to encourage the developers of the housing industry, the present legal framework relating to acquisition of land for the housing industry needs to be strengthened.

Under the above said circumstances the private sector is not being encouraged so the legislature or apex court of Pakistan by looking into the ground realties and bitter truths in housing industry should take a sympathetic view by giving a right to the housing developers to challenge the amount of market value of the land to be acquired for the housing society. This remedy has been provided by the apex court of India to housing developers in India.

\section{Recommendations and Suggestions needed to be taken to protect the developers of the Housing Industry from exploitation.}

The following steps needs to be taken to encourage the developers of the housing industry in Pakistan to do housing activity to achieve the goal of housing for all and to eliminate the malpractices and blackmailing.

\section{As a Long-Term Solution, Computerization of all Land Record System.}

To make the land revenue record foolproof the land revenue record should be computerized. This would help to stop the overnight changing of the nature of the land from agriculture to commercial to charge high prices from the developers of the housing societies.

\section{As a Short-Term Measure, Seal the Land Record of The Relevant Area.}

As a short-term measure and before the computerization of revenue record is done. Before the issuance of notification under the Act the land record of the area concerned in which the housing society is being formed must be sealed to unable the revenue officials to change the nature of the land. The best time to perform this act is before the information is leaked about the formation of a housing society in an area (Ishaq, 1983).

Pages of mutation must be signed in order to stop the practice of replacing and adjusting the pages in the record containing unauthorized entries. Due to the problems faced like above the Supreme Court had to declare that an entry in the revenue record as to the nature of the land may not be conclusive (1991 SCMR 2164).

\section{Improvement in the Registration Act 1908.}

Non testamentary documents relating to immovable property are registerd on the basis of description of property which is the only stipulation to identify the property (Registration Act 1908, 2015). If the registration of non-testamentary documents pertaing to immovable property which is situated in more than one district is required to be done it should be done by providing number of true copies of the map or plan equal to the number of districts should be provided. These couple of sections of Registration Act needs to 
be amended in such a manner that the officials of the revenue department cannot change the nature of the land from the agriculture to commercial etc., and if there is a need to do so it should be done in collaboration with the authorities entrusted with the task of town planning or development authorities.

\section{Removal of Dichotomy between Land Acquisition Act and Roles of Development Authorities.}

There is no precondition of land in the Land Acquisition Act by a private housing company or cooperative housing society. But contrary to it the development authorities in the provinces have been applying the rules for the grant of NOCs' to these housing companies and cooperative housing societies. These rules contain condition of ownership/possession of major portion of land before the grant of no objection certificate to start a housing society.

Thus, there is a dichotomy in the Act and the Rules of the development authorities. The condition of ownership of major portion of land has heated up the prices of the land and due to this reason housing has become only a dream for the middle class and poor class of Pakistan.

Private housing companies and other major housing developers can afford to purchase a major portion of land before the start of housing scheme but cooperative housing societies which are formed by the poor people cannot afford to purchase a big chunk of land in one go. Due to the above said situation the last door the last hope available to the poor class of Pakistan to have their own house is likely to be affected badly.

\section{Relaxation of the Condition to purchase Big Chunk of Land before getting NOC from Development Authorities.}

The present practice of large-scale acquisition of land is a direct result of the rules of the regulatory authorities to grant NOC. This condition should be relaxed to the extent as determined by each province before grant of NOC by the regulatory authorities. The relaxation of condition will help neutralize the negative effect on the growth of housing industry and also save the cooperative housing societies formed by the people of modest means (cooperative housing societies) from becoming extinct from the housing industry of Pakistan. This relaxation would help each province to prescribe a portion of land (whatever it may be) for the grant of NOC by keeping in view the political, social, cultural and economic priorities of each province.

\section{Protection of The Developers of The Housing Industry from The Owners of Small Portion of Lands being acquired under the Act.}

Generally when the developers of the housing societies purchase a major portion of land, it was 80 percent under the Punjab Private Site Regulations 2005 and now, under the Rules of 2010 it has been enhanced up to 90 percent, and submit the lay out plan of the whole 100 percent housing scheme to the development authority for the grant of NOC.

When after the grant of NOC, when these housing developers proceed to acquire this small portion of land the prices of this small chunk of land are dictated by the owners of this small piece of lands in collision of land revenue officials.

In order to protect the housing developers from the blackmailing at the hands of such land owners the relevant section of the Land Acquisition Act 1894, needs to be amended in such a manner that the price of this small chunk of land is paid equal to the value of land already purchased by the developer of the housing society. 


\section{Divest the revenue officials of the power to change in land use.}

An amendment should be introduced in the Registration Act 1908 in such a manner that the revenue officials cannot change the nature of the land without consultation of officials dealing with town planning.

\section{Conclusion}

From the above said discussion it is very much clear that there is a clear contradiction between theory and practice being followed by the developers of the housing industry in Pakistan for the acquisition of land to perform housing activity. Government of Pakistan needs to take immediate steps to strengthen the Legal Framework relating to housing industry to enable the developers of the housing industry to perform housing activity in a smooth way. After introduction of necessary changes in the Legal Framework the gap between theory and practice can be bridged. The research may be concluded by saying that the present law regarding acquisition of land needs to be strengthened in the light of international best practices. It is also recommended to add housing the definition of public purpose.

\section{References}

A. Natesa Asari Vs State of Madras, AIR (1954) Madras 481.

Abdul Rauf Khan Vs Land Acquisition Collector, (1991) SCMR 2164.

Bagwat Dyal Vs Union of India and others, AIR (1959) Punjab 544.

Bhagwat Dayal and others Vs Union of India, AIR (1959) Punjab 544.

Bhagwat Dayal and others Vs Union of India, AIR (1959) Punjab 544.

Chairman WAPDA Vs Ghulam Shabbir, (2009) SCMR 1051.

Chand Pvt. Ltd Housing Company Vs Land Acquisition Collector, (1981) H 213 (FB).

Chiniot Cooperative Housing Society Ltd Vs Govt. of Punjab, PLD (2016) Lahore 293.

Chinniot Cooperative Housing Society Ltd through its President Vs Govt. of Punjab through Secretary Cooperative Dept. and others, PLD (2016) Lahore 293.

Constitution of Islamic Republic of Pakistan, (2016). Article 24, Seventh Edition, Al Qanun Publishers, Lahore.

Daily Dawn (News Paper), 4 September 2017.

Das, S., \& Mathur, H. M. (2006). The Land Acquisition Laws in India: An Overview with Some Suggestions for Amendment. New Delhi.

Defence Department of Pakistan through Secretary Ministry of Defence Vs Province of Punjab and others, (2006) SCMR 402

Fauji Foundation and others Vs Sami-Ur -Rehman, PLD 1983 SC 457.

Fauji Foundation Vs Sami ur Rehman, PLD 1983 SC 457.

Gates, P. W. (1968). History of public land law development (Vol. 62). US Government Printing Office.

Gulshan Hussain Vs Commissioner Revenue, Lahore, (2000) YLR1711.

Hamabai Framjee Vs Secretary of State for India, AIR 1914PC20.

Haq Nawaz Khan and others Vs Rab Nawaz and others, 1992 SCMR 993.

http://www.unhabitat.org visited on 1-9-2016.

Hyderabad Development Authority Vs Abdul Majeed, PLD 2002 SC 91.

Ishaq Ali Qazzi, Punjab Land Acquisition Rules 1983, Section 5, Manual of Land Acquisition Laws, Insaf Law Book House, Rawalpindi, 2019.

Islamia University Bahawalpur through V.C Vs Khadim Hussain and 5 others, 1990 MLD 2158.

Land Acquisition Act 1894, Issac Ali Qazi, First Edition, Insaf Law House, Rawalpindi.2019.

LDA through D.G LDA and others Vs Messers. Shaukat and Raza Pvt Ltd, 2011 YLR 3060.

M.Ashraf Vs District Collector, Jehlum, PLD2002 SC 706.

Manickchand Mahata Vs Corporation of Calcutta, ILR 48 CAL.916.

Medium Term Development Framework 2005-10. By planning commission of Pakistan, Page 183.

Miah Rafat Mahmood and 5 others Vs D.G LDA, Lahore and 3 others,2016 CLC 408. 
Military Estate Officer, Quetta Circle Quetta Cantt. Vs Assistant Commissioner cum Collector Quetta, 1997 CLC 556.

Musamiyam Imam Hyder Buksh Rizvi Vs State of Gujrat and others, AIR 1971 Gujarat 158.

Mushtaq Ahmad Khan, Land Acquisition Act1894, Fifth Edition, Punjab Law Book House, Lahore,2015.

Nadeem, A. H. (2020). Pakistan: The Politics of the Misgoverned. Taylor \& Francis.

National Housing Policy, (2001). By Ministry of Housing and Works, Page 45.

Nazir Ahmaed and 8 others Vs Commissioner, Lahore, 2000 MLD 322.

Nazir Ahmaed and 8 others Vs Commissioner, Lahore, 2000 MLD 322.

Nazir Ahmed and 8 others Vs Commissioner, Lahore, 2000 MLD 322.

Pak. Steel Mill Corporation Ltd Vs Deputy Commissioner Karachi, 1989 SCMR 812.

Pakistan through Military Estate Officer Kharian Cantt. Vs Abdul Hayee Khan through Legal Heirs and 5 others, PLD 1995 SC 418

Pir Khan Vs Military Estate Officer, Abbotabad, PLD 1987 SC 485.

Qutub Ali Vs Custodian Evacuee Trust Property, Lahore, PLD 1964 SC 60.

R.L Arora Vs State of Utter Pradesh and others, AIR 1962 SC 764

R.L. Aurora Vs State of Utterpradesh and others, AIR 1958 Allahabad 872.

Ram Das Vs Land Acquisition Collector, AIR 1959 PB 479.

Ram Das Vs Land Acquisition Collector, ILR 18CAT.99(PC)

Ram Naryan and others Vs State of Bihar, AIR 1978 Patna 136.

Rizwan, S. (2017). Legal Frame Work Relating To Real Estate Sector in Pakistan: A Critical Analysis. Islamabad Law Review, 1(3), 85-III.

S.M.T Somnawanti Vs State of Punjab, AIR 1963 SC 151.

Satiyana Raju Vs Hari Hara Prasad and others, AIR 1955 Andhra 184.

Suleman Dawood Vs LDA through D.G, 2008 CLD 850.

Syed Nazar Abbas Naqui Vs Commissioner, Sargodha, 1996 SCMR 1277.

The Constitution of the Islamic Republic of Pakistan, 1973

The Land Acquisition Act-1894, Section 18, Third Edition, P.L.D Publishers, Lahore, 2016.

The State of Bihar Vs Sir Kameshwar Singh, AIR 1952 SC 252.

Vera Raj Hauachariar and others Vs Secretary of State for India, AIR 1925 Mad 837. 